\title{
BEYOND NOISE: GASEOUS POLLUTION OF MOTORCYCLES' REPLACEMENT EXHAUST SYSTEMS IN SAO PAULO
}

\author{
FORCETTO, A. L. S. ${ }^{1}$; DAEMME, L. C. ${ }^{2}$ \\ 1 - CETESB - Environmental Company of Sao Paulo State, Brazil \\ 2 - LACTEC Institutes, Parana, Brazil \\ E-mails: aforcetto@sp.gov.br, luiz.carlos@lactec.org.br
}

\begin{abstract}
Motorcycles in Sao Paulo Metropolitan Region (SPMR) are in 2014 about one million units or $12 \%$ of all registered vehicles, with a presence of $15 \%$ in the urban traffic flow and contributing with of $21 \%$ of all $\mathrm{CO}, 12.8 \%$ of $\mathrm{HC}$ and $2.1 \%$ of NOx emitted from vehicles. However, despite all gains in reducing gaseous emissions in new vehicles, about $16 \%$ of the motorcycles are running with Non Original Exhaust Systems (NOES), that in Brazil usually have no catalyzer and fewer internal components than an original equipment (OEM), in order to reduce gas flow counterpressure and to produce a typical loud sound like "popping". NOES brings an individual increment of 1.2 to 12 times in emissions of $\mathrm{CO}, \mathrm{HC}$ and NOx comparing with OEM, drawing motorcycles back to levels before Brazilian Control Program PROMOT phase M3, equivalent of Euro 3. The objective of this article is to quantify the environmental impact in SPMR due to gaseous emissions of motorcycles equipped with NOES.
\end{abstract}

Keywords: gaseous pollution, tampered motorcycles, exhaust system

\section{INTRODUCTION}

Motorcycles in Brazil in the past were seen just as "hobby vehicle", so in 1990s there were only two manufacturers, and the internal sales amounted to just 53,000 units/year. This tendency changed in the late 1990s and early 2000s, reaching its upper point at 2011, when 1.9 million units were sold, however recent gross production was decreased to about 1.4 million in 2014 [1]. The growth in the motorcycle fleet from 2004 to 2014 was about 223\%, much greater than the $121 \%$ growth in the general fleet (cars plus heavy duty plus motorcycles) and the $12 \%$ growth in the population [1]. This can be explained by a preference for individual over public transportation due to the precariousness of the latter and the emergence of a new professional category: the moto-freighters, also known as "motoboys", dedicated to deliver small goods, documents and fast-food [2, 3].

The impact of the growing fleet of motorcycles in the urban environment was recognized by the Brazilian Government, which established regulations in 2003 for gaseous emissions for new motorcycles sold in the internal market, including them as 
part of the Air Pollution Control Program for Motor Vehicles (PROCONVE), named as Air Pollution Program for Motorcycles and Similar Vehicles (PROMOT) [4]. However, a problem related to in-use motorcycles persists, the same faced in many parts of the world: the change of original mufflers for Non-Original Exhaust Systems (NOES). Their particular characteristics undermine all the gains brought by regulations and contribute to worsening the urban environment of Sao Paulo Metropolitan Region (SPMR). The objective of this article is to quantify the environmental impact in SPMR with regard to gaseous emissions of motorcycles equipped with NOES.

\section{NOES CHARACTERISTICS}

NOES in Brazil are replacement exhaust systems freely sold in aftermarket, cheaper than an Original Equipment from Manufacturer (OEM) and used by riders in order to improve performance and/or produce more noise. Usually they have no catalyzer in order to keep the selling price lower than that of an OEM system but resulting in a huge increment in gaseous emissions. They also have fewer internal parts than an OEM in order to reduce gas flow counter-pressure, but generating much more noise.

There are three main types sold in Brazilian aftermarket; the "estralador" ("popper") type, shown in Figure 3, is the best-seller muffler with about $90 \%$ of the sales. Due to the fact that it has no internal components to absorb noise, it produces a loud "popping", especially when the rider runs the engine in median-high velocities and suddenly closes the throttle; an "estralador" can generates noise $12 \mathrm{~dB}(\mathrm{~A})$ higher than an OEM [5]. Others types found in the market are "similar to original" that reproduces OEM's internal construction and external design and "sport", just a punched pipe with a box outside it, filled with glass wool.

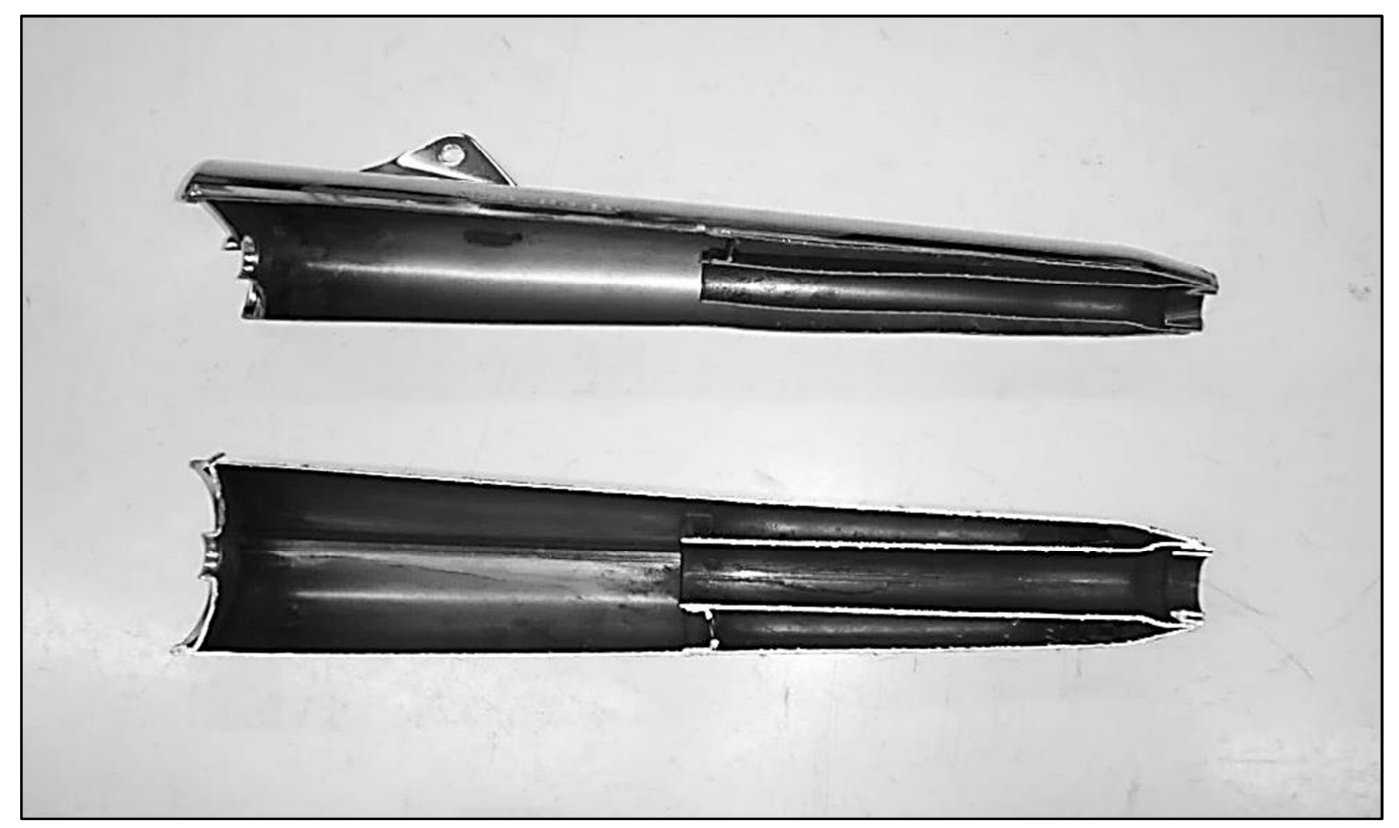

Figure 1: Internal view of a "estralador" muffler, without catalyzer 


\section{METHODS}

To analyze NOES' environmental impact, this work is divided into three parts. The first part calculates motorcycles' contribution to gaseous emissions in SPMR, secondly it is measured the increasing of emissions when NOES replaces an OEM while the third part estimates the impact on gases of the use of NOES in SPMR.

The first step, motorcycles' specific contribution, is based on the CETESB (Environmental Company of Sao Paulo State)/Brazil gaseous emissions inventory methodology, fully detailed in the report "Emissoes veiculares no estado de Sao Paulo - 2014" [6], where general vehicular gaseous emission are calculated weighting fleet quantity and composition, fuel consumption and mileage average among other data stored since 1979 to now. It was performed on these spreadsheets a specific study focused on motorcycles.

The second part, measuring NOES gaseous emissions, was performed using a dynamometer with two motorcycles, a 2009 model, $125 \mathrm{~cm}^{3}$, phase PROMOT M3, equivalent to Euro 3, and a 2014 model, $150 \mathrm{~cm}^{3}$ (PROMOT M4 or Euro 4), within their respective test cycles (European Directive 97/24/EC or WMTC). Samples were taken in two modes: running with an OEM exhaust system, it was collected these samples at the pipe end and before the catalyser, because that is the main difference between OEM and NOES in respect of gases.

The third part of this work estimates NOES' environmental impact by inserting NOES specific data into the spreadsheets for CETESB gaseous emissions inventory and analyzing these results.

\section{RESULTS AND DISCUSSION}

\subsection{Motorcycles' contribution in gaseous emissions}

Sao Paulo State has the biggest motorcycle fleet in Brazil; in 2014 they are about 2.6 million of units [6] or $21.4 \%$ of the Brazilian fleet [1]. Just in SPMR are registered almost one million units; this is $12 \%$ of all registered vehicles and represents $34 \%$ of the motorcycle state fleet [6]. SPMR urban traffic flow is composed of about $80 \%$ of light duty vehicles, $15 \%$ of motorcycles and $5 \%$ of heavy duty vehicles, mainly buses (3 to 4\%) [7]. In comparison with others regions, motorcycle presence in SPMR traffic is a median term, it is more than in the USA (3\% of the flow), Canada (5\%) and Europe (11.5\%) but much less than in Asian countries such as Taiwan (68\%), India $(72 \%)$ and Indonesia (80\%) [8, 9], and, like these Asian countries, there is here a prevalence $(96 \%)$ of small capacity engines, below $250 \mathrm{~cm}^{3}[1]$.

The main vehicular gaseous pollutants in SPMR are hydrocarbons $(\mathrm{HC})$ from unburned and evaporated fuel; nitrogen oxides (NOx) and carbon monoxide (CO) from engine combustion, besides aldehydes $(\mathrm{CHO})$, sulphur dioxide $\left(\mathrm{SO}_{2}\right)$ and particulate matter (PM) [6]. Figure 2 shows the relative contribution of each type of vehicle in the generation of pollutants, highlighting those coming from motorcycles: 
$21.0 \%$ of all $\mathrm{CO}, 12.8 \%$ of $\mathrm{HC}$ and $2.1 \%$ of NOx. Their annual emissions amount to about $34.2 \mathrm{t}$ of $\mathrm{CO}, 4.4 \mathrm{t}$ of $\mathrm{HC}$ and $1.1 \mathrm{t}$ of NOx. The pollution caused by motorcycles has a greater weight than their presence in the traffic and their fuel consumption so if many motorcycles are present in the traffic, can be expected higher levels of $\mathrm{CO}$ and $\mathrm{HC}$.

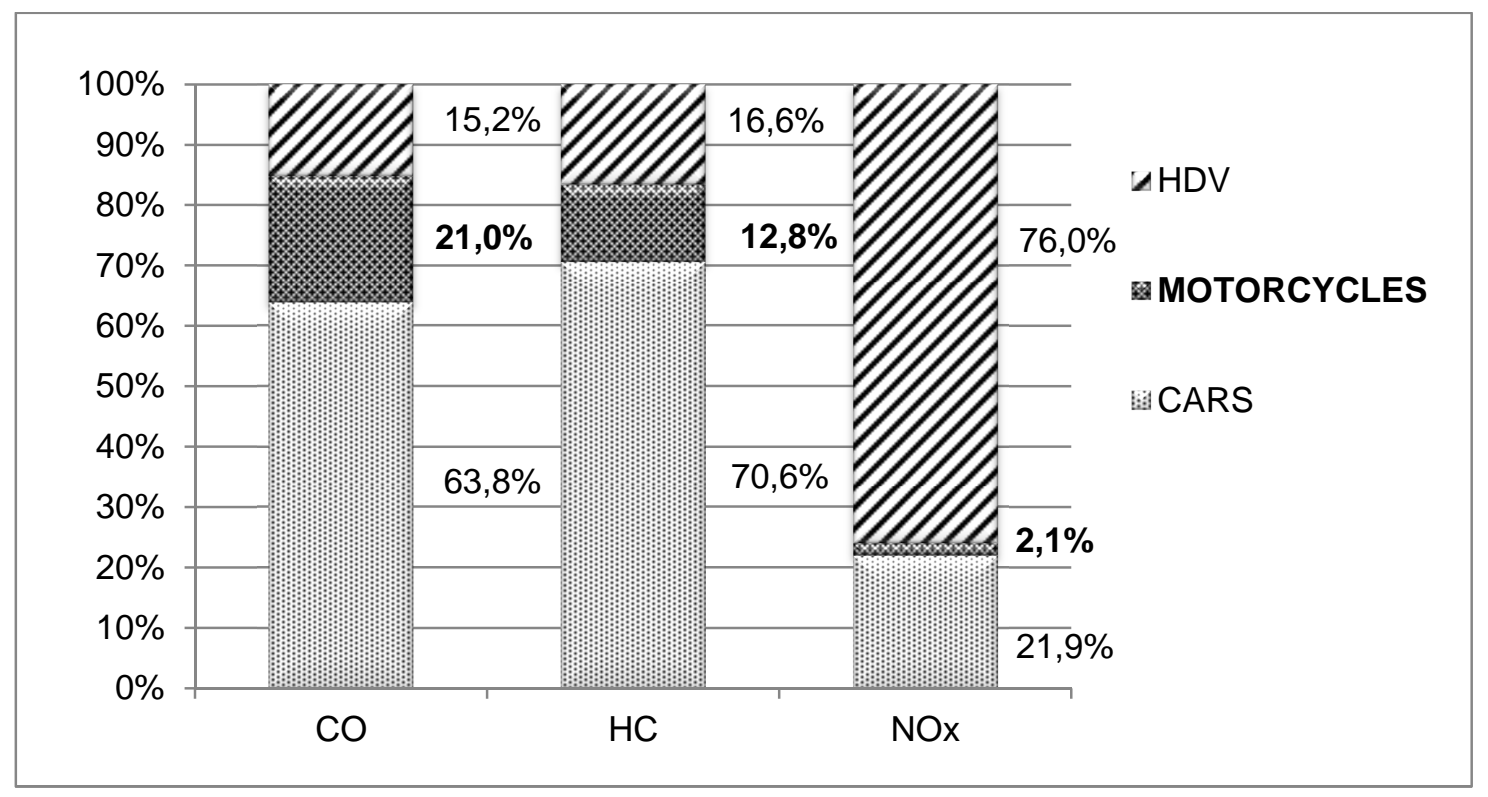

Figure 2: $\quad$ Relative contribution to gaseous emissions in SPMR [6, adapted]

\subsection{NOES influence in gaseous emissions}

Brazilian gaseous emissions' phases are close to the Europe development, although with distinctive names or in different periods. Table 4 has a summary of these phases:

Table 1: $\quad$ Brazilian motorcycle phases to gaseous emissions [4]

\begin{tabular}{|c|c|c|c|c|c|c|}
\hline \multirow{2}{*}{$\begin{array}{c}\text { Brazilian } \\
\text { Phase }\end{array}$} & Europe & Period & \multicolumn{3}{|c|}{ Limits $\mathbf{( g / k m )}$} & \multirow{2}{*}{ Technology } \\
\cline { 4 - 6 } & & & Co & HC & NOx & \\
\hline M1 & Euro 1 & $2003-2006$ & 13.0 & 3.0 & 0.3 & $\begin{array}{c}\text { Carburetor + } \\
\text { adjustments }\end{array}$ \\
\hline M2 & Euro 2 & $2006-2008$ & 5.5 & 1.2 & 0.3 & $\begin{array}{c}\text { Carburetor + } \\
\text { adjustments }\end{array}$ \\
\hline M3 & Euro 3 & $2009-2014$ & 2.0 & 0.8 & 0.15 & $\begin{array}{c}\text { Carburetor or } \\
\text { Fuel injection } \\
+ \text { catalyzer }\end{array}$ \\
\hline M4 & Euro 4 & $2014-$-now & 2.0 & 0.8 & 0.15 & $\begin{array}{c}\text { Fuel injection } \\
\text { + catalyzer }\end{array}$ \\
\hline
\end{tabular}


Because NOES have no catalyzers it was expected that these exhaust systems would push emissions up beyond M3/Euro 3 limits, even in a M4 motorcycle. This is partially true because, for $\mathrm{CO}$, the tested vehicles exceed or are very close to the $\mathrm{M} 3$ limits and, for NOx, they greatly exceed these, as summarized in Table 2. For HC, they are still adhering to legal parameters, but with a huge increment, particularly to the 2014 model, what means that use of NOES can degrade environmental quality back to 2008 levels or earlier: a loss of eight years of vehicle engineering development.

Table 2: Comparison of OEM and NOES emissions $(\mathrm{g} / \mathrm{km})$

\begin{tabular}{|c|c|c|c|c|c|}
\hline & \multirow{2}{*}{\multicolumn{2}{|c|}{$\begin{array}{c}2009 \text { Model - } 125 \mathrm{~cm}^{3} \\
\text { Phase M3 / E3 }\end{array}$}} & \multirow{2}{*}{\multicolumn{2}{|c|}{$\begin{array}{c}2014 \text { Model - } 150 \mathrm{~cm}^{3} \\
\text { Phase M4 / E4 }\end{array}$}} \\
\hline & & & & & \\
\hline \multirow{4}{*}{$\mathrm{CO}$} & OEM & 1.818 & Ok & 0.522 & ok \\
\hline & NOES & 2.241 & Fail & 1.939 & close to limit \\
\hline & M3/M4 limit [4] & \multicolumn{4}{|c|}{2.0} \\
\hline & Increment & \multicolumn{2}{|c|}{$1.23 x$} & \multicolumn{2}{|c|}{$3.71 x$} \\
\hline \multirow{4}{*}{$\mathrm{HC}$} & OEM & 0.257 & Ok & 0.069 & Ok \\
\hline & NOES & 0.509 & Ok & 0.253 & Ok \\
\hline & M3/M4 limit [4] & \multicolumn{4}{|c|}{0.8} \\
\hline & Increment & \multicolumn{2}{|c|}{$1.98 x$} & \multicolumn{2}{|c|}{$3.67 x$} \\
\hline \multirow{4}{*}{ NOx } & OEM & 0.085 & Ok & 0.063 & Ok \\
\hline & NOES & 0.417 & Fail & 0.735 & Fail \\
\hline & M3/M4 limit [4] & \multicolumn{4}{|c|}{0.150} \\
\hline & Increment & \multicolumn{2}{|c|}{$4.91 x$} & \multicolumn{2}{|c|}{$11.67 x$} \\
\hline
\end{tabular}

\subsection{NOES' environmental impact}

According to FORCETTO [5], were observed the presence in the SPMR traffic flow of about $16 \%$ of motorcycles with NOES. In Europe and in Japan this proportion is worst, according to ACEM [11] in Europe 35\% of motorcycles and $65 \%$ of mopeds (51\% in general) have illegal exhaust systems and, in Japan, the Ministry of the Environment these amount to about $40 \%$ [12]. So, in this paper, all estimations were made upon the observed proportion and also for an increment to $35 \%$ of NOES in SPMR fleet.

NOES is responsible for a rise of all emissions but this rise is not so high because catalyzers were introduced in Brazilian motorcycles just after 2009; nevertheless there is a tendency for these emissions to grow even more as, at the present time, NOES (without catalyzer) are replacing newer OEMs with built-in catalyzer exhaust systems. In Table 3 the impact of NOES can be seen, especially in $\mathrm{HC}(+3.7 \%$ or 
$+1,277 \mathrm{t} / \mathrm{year})$ and $\mathrm{CO}(+5.2 \%$ or $+230 \mathrm{t} / \mathrm{year})$. It is estimated that $35 \%$ of motorcycles with NOES will produce an additional $\mathrm{HC}$ emissions of $+8.1 \%$ or 2,793 t/year and $+11.4 \%$ or $504 \mathrm{t} /$ year of $\mathrm{CO}$. The absolute increment in NOx is very high but the level of influence on the environment is not so high due to the fact of HDV are the main source and motorcycles contribute only with $2 \%$ of NOx general emission.

\begin{tabular}{|c|c|c|c|}
\hline & & $\begin{array}{l}\text { With } 16 \% \text { NOES } \\
\text { (actual) }\end{array}$ & With $35 \%$ NOES \\
\hline \multirow{3}{*}{$\mathrm{HC}$} & OEM & 34,272 & 34,272 \\
\hline & NOES & 35,549 & 37,065 \\
\hline & Difference & $+3.7 \%$ & $+8.1 \%$ \\
\hline \multicolumn{2}{|c|}{ Increment: } & 1,277 & 2,793 \\
\hline \multirow{3}{*}{$\mathrm{CO}$} & OEM & 4,408 & 4,408 \\
\hline & NOES & 4,638 & 4,912 \\
\hline & Difference & $+5.2 \%$ & $+11.4 \%$ \\
\hline \multicolumn{2}{|c|}{ Increment: } & 230 & 504 \\
\hline \multirow{3}{*}{ NOx } & OEM & 1,134 & 1,134 \\
\hline & NOES & 1,444 & 1,811 \\
\hline & Difference & $+27.3 \%$ & $+59.7 \%$ \\
\hline \multicolumn{2}{|c|}{ Increment: } & 310 & 677 \\
\hline
\end{tabular}

\section{CONCLUSIONS}

NOES' main problems are related to noise and gaseous emissions, and it is possible to see a great increase in all pollutants, harking back to levels before the introduction of PROMOT M3 / Euro 3. The presence of $16 \%$ of NOES in the motorcycle fleet is lower than in Europe and Japan, but the environmental impact is higher because Brazilian fleet is bigger and the impact is likely to get worse with the growing tendency of the fleet to use NOES.

Although moto riders can argue about safety or personal preferences in their motorcycles' sound, NOES are delivering a huge impact on SPMR urban environment that cannot be neglected. The high level of increasing gases and noise emissions due to NOES is a degradation factor of the SPMR environment that demands strong and urgent action to reduce or even to banish this kind of 
component when sold or used with no catalyser and unable to fulfil legal emissions limits.

\section{REFERENCES}

[1] ABRACICLO - Brazilian Association of Motorcycles, Mopeds, Bicycles and similar. Anuário da Indústria brasileira de duas rodas 2015. Sao Paulo, 2015. Available at <http://www.abraciclo.com.br/anuario-de-2015>. Acess in Aug $/ 21^{\text {st }} / 2015$.

[2] VASCONCELLOS, E. A. O custo social da motocicleta no Brasil. Revista dos Transportes Públicos - ANTP, Sao Paulo, year 30/31, pp. 127-142, $3^{\text {rd }}$ and $4^{\text {th }}$ trimesters, 2008.

[3] ABRACICLO - Brazilian Association of Motorcycles, Mopeds, Bicycles and similar. Anuário da Indústria brasileira de duas rodas 2013. Sao Paulo, 2013. Available at <http://www.abraciclo.com.br/anuario-2013>. Acess in Mar/ $19^{\text {th }} / 2014$.

[4] IBAMA - Brazilian Institute of Environment and Natural Renewable Resources. Programa de controle de poluição do ar por veículos automotores Proconve/Promot/lbama. IBAMA: Brasília, DF, 2011.

[5] FORCETTO, A. L. S. Poluição sonora urbana: a influência de modificações em escapamentos de motocicletas na emissão de ruído, MSc dissertation, Faculdade de Saúde Pública da Universidade de São Paulo - FSP-USP, Sao Paulo, 2016.

[6] BALES, M. (coord.) Emissões veiculares no estado de Sao Paulo - 2014. São Paulo: CETESB, 2015.145 p. Available at $<$ http://veicular.cetesb.sp.gov.br/relatorios-e-publicacoes/>. Acess in Dec $/ 16^{\text {th }} / 2015$.

[7] CET - Traffic Engineering Company of São Paulo City. Pesquisa de monitoração da fluidez: desempenho do sistema viário principal, volume e velocidade - 2013. Sao Paulo: CET, 2014. Available at $<$ http://www.cetsp.com.br/sobre-a-cet/relatorios-corporativos.aspx>. Acess in Apr/29th $/ 2015$.

[8] IMMA - International Motorcycle Manufacturers Association. The shared road to safety: a global approach for safer motorcycling. Geneva, Switzerland, 2014. Available at <http://immamotorcycles.org/sites/all/themes/business/media/The_Shared_Road to_Safety-IMMA_May_2014.pdf?pdf=Imma-Publications>. Acess in Feb/05 ${ }^{\text {th }} / 2015$.

[9] CHANG, T., et al. A modified Nordic prediction model of road traffic noise in a Taiwanese city with significant motorcycle traffic. Science of total environment, Amsterdam, Netherlands, №. 432, pp. 375-381, July/2012. Available at <http://www.sciencedirect.com/science/article/pii/S0048969712008315>. Acess in May $/ 11^{\text {th }} / 2015$.

[10]LELONG, J. et al. Towards a reduction of noise emission of powered two-wheels - part 1. In: INTERNOISE 2014, Melbourne, Australia. On line conference proceedings. Melbourne, Australia: Australian Acoustics Society, 2014. Available at 
$<$ http://www.acoustics.asn.au/conference_proceedings/INTERNOISE2014/paper s/p360.pdf>. Acess in Apr/22 $/ 2015$.

[11]ACEM - Association des Contructeurs Européens de Motocycles. Striving against traffic noise: how powered two-wheelers can contribute. Brussels, Belgium, 2014. Available at <http://www.acem.eu/index.php/policyaccess/environment/noise-reduction $>$. Acess in Oct $/ 30^{\text {th }} / 2014$.

[12]UNECE - United Nations Economic Commission for Europe - Ministry of the environment, Japan. Current framework of vehicle noise regulation in Japan - Informal Document GRB-56-18. Geneva, Switzland: UNECE, 2012. Available at <http://www.unece.org/fileadmin/DAM/trans/doc/2012/wp29grb /ECE-TRANSWP29-GRB-56-inf18e.pdf $>$. Acess in Mar/25 $/ 2014$. 